\title{
Robust development of a CNC turning process
}

\author{
Laurentiu - Aurel Mihail ${ }^{1, *}$ \\ ${ }^{1}$ Transilvania University of Brasov, Manufacturing Engineering Department, 500466 Mihai Viteazul \\ 5 , Romania
}

\begin{abstract}
The article present an optimization study developed on a CNC HSM center for the external turning of spheroidal graphite iron precision mechanics parts. For isolating as much as possible the thermal error effects on the machining accuracy study, there were developed studies for statistically controlling the machining process and for mastering the measuring process, also. For assessing the process there were measured the dimensional critical quality characteristics. As analytical tools, were designed experiments applying the Taguchi Method, and the results are analyzed with ANOM method.
\end{abstract}

\section{Introduction}

The cutting processes are a base technology, despite of the new trends in manufacturing, as it is the additive manufacturing concept. Even if the cutting technologies are generally considered matured (especially within the industrial field), there it is enough room for optimizations taking account of the developments trends: cutting machines with increased dynamics, optimized or new cutting tools materials and geometries, new materials to be machined, etc.

In this context, the current study presents an optimization research for improving the turning process in a real industrial environment case.

The paper is organized in the following manner. An overview of the parameter design based on the Taguchi method is given first. Then, the parameter design with the characteristics is introduced. The experimental detail of using the parameter design to determine and analyze the optimal cutting parameters in turning operations is described next. Finally, the paper concludes with a summary of this study.

\section{Robust engineering by Taguchi Method}

\subsection{The concept of Robust Engineering / Taguchi Method}

The Robust Engineering approach, as an innovative concept applied through the Taguchi Method, can be used for the optimization of the industrial processes starting with the earliest product and process development lifecycle phases.

*Corresponding author: L.Mihail@unitbv.ro 
Generally, within the organizational management, product development is considered a major tactic for profitability. It consists of the following two aspects [1]:

- (1) Product quality: what consumers desire (functions or appearance);

- (2) Engineering quality: what consumers do not want (functional variability, running cost, pollution).

The manufacturing process must take in considerations the aspects regarding the product development, and, for achieving these goals, it can be designed in an optimal manner using the Robust Engineering.

Quality engineering is robust design based on the following three procedures:

- (1) Orthogonal array,

- (2) SN ratio, and

- (3) Loss function.

These three procedures are not robust design per se because they are used to evaluate technical means, products or processes. To design robustness, it is required to understand the meaning of robust design before considering technical or management means [1]. Those who consider practical means are engineers and production people.

Robust design (including product and process design) generally means designing a product that can function properly under various conditions of use or a process that is nonsensitive at the noise (see the Fig. 1 and Fig. 2) [2]. The noise factors being external controllable or not controllable factors.

The objective of the parameter design is to optimize the settings of the process parameter values for improving performance characteristics and to identify the product parameter values under the optimal process parameter values.

In addition, it is expected that the optimal process parameter values obtained from the parameter design are insensitive to the variation of environmental conditions and other noise factors. Therefore, the parameter design is the key step in the Taguchi method to achieving high quality without increasing cost.

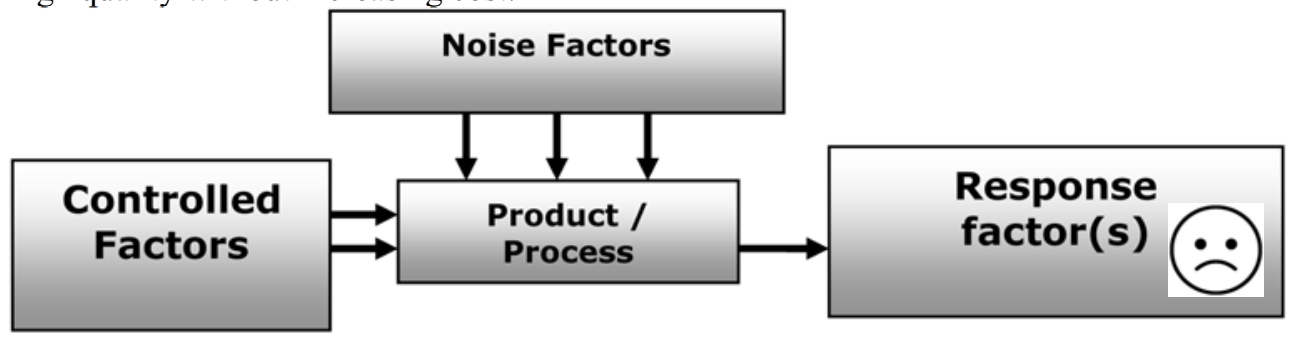

Fig. 1. The generic Parameter Diagram for the non-robust processes.

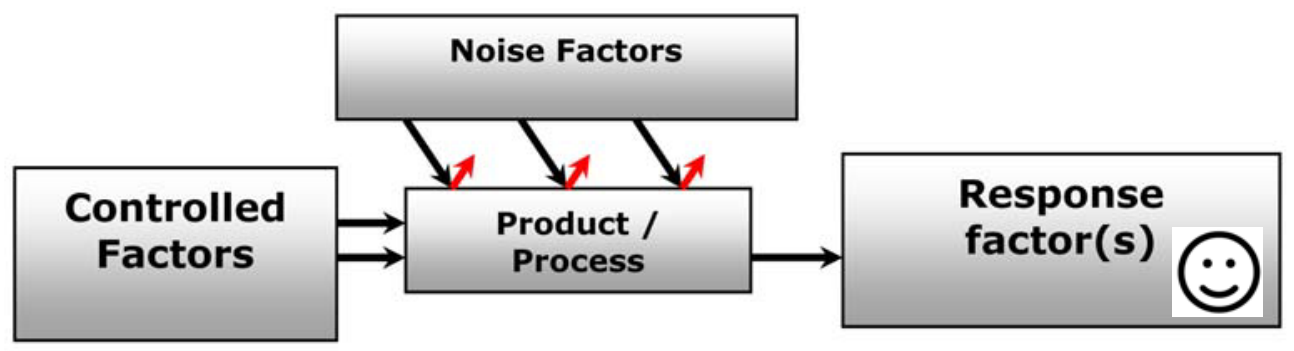

Fig. 2. The generic Parameter Diagram for the robust processes. 


\subsection{State-of-the-art of using Robust Engineering on CNC turning process optimization}

Dedicated state - of - the art literature present extensive approaches regarding the methods used for optimization of the cutting process. Therefore, the [3] reference present researches regarding the next techniques for the optimization of industrial processes:

- (1) Lagrange's method;

- (2) Geometric programming;

- (3) Goal programming;

- (4) Dynamic programming;

- (5) Fuzzy logic;

- (6) Genetic algorithm;

- (7) Scatter search;

- (8) Taguchi method;

- (9) Response surface methodology.

The Robust Engineering is becoming more and more used for the optimization of the manufacturing by cutting processes, too. One of the most used cutting process within the worldwide manufacturing industry is the turning process, a relatively simple operation but that continues to need applied research especially because of the cutting high performance dynamics, workpiece materials and cutting tools. Therefore, within the Table 1 it is presented a brief state of the art containing some studies on the same argument, treated within this paper.

Table 1. State of the art of several researches regarding the use of Taguchi Method on optimization of turning operation.

\begin{tabular}{|c|c|c|c|c|c|c|}
\hline 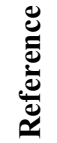 & $\begin{array}{l}\text { Optimizati } \\
\text { on method }\end{array}$ & $\begin{array}{c}\text { Optimization } \\
\text { criteria }\end{array}$ & $\begin{array}{c}\text { Optimization } \\
\text { parameters }\end{array}$ & $\begin{array}{c}\text { Part's } \\
\text { material }\end{array}$ & $\begin{array}{c}\text { Factorial } \\
\text { lattice }\end{array}$ & $\begin{array}{c}\text { Data } \\
\text { analysis }\end{array}$ \\
\hline [4] & $\begin{array}{c}\text { Hybrid: } \\
\text { Taguchi } \\
\text { Method\& } \\
\text { Differential } \\
\text { evolution } \\
\text { algorithm }\end{array}$ & Unit cost & $\begin{array}{c}\text { Cutting } \\
\text { parameters:cut } \\
\text { ting speed, } \\
\text { cutting feed, } \\
\text { cutting depth }\end{array}$ & Metal & $\mathrm{L}_{16} 5^{4}$ & $\begin{array}{c}\text { SNR(STB } \\
\text { )\& } \\
\text { ANOVA }\end{array}$ \\
\hline [5] & $\begin{array}{l}\text { Hybrid: } \\
\text { Taguchi } \\
\text { Method } \\
\text { \&Grey } \\
\text { relational } \\
\text { analysis }\end{array}$ & $\begin{array}{c}\text { Surface } \\
\text { quality: } \\
\mathrm{R}_{\mathrm{a}} \text { and } \mathrm{R}_{\mathrm{t}} \\
\text { roughness } \\
\text { and circularity }\end{array}$ & $\begin{array}{c}\text { Cutting } \\
\text { parameters: } \\
\text { cutting speed, } \\
\text { cutting feed, } \\
\text { cutting depth } \\
\& \\
\text { cutting fluid }\end{array}$ & $\begin{array}{c}\text { high } \\
\text { carbon } \\
\text { high } \\
\text { chromium } \\
\text { alloy tool } \\
\text { steel }\end{array}$ & $\mathrm{L}_{9} 3^{4}$ & $\begin{array}{c}\text { SNR(STB } \\
\text { )\& } \\
\text { ANOVA }\end{array}$ \\
\hline [6] & $\begin{array}{l}\text { Taguchi } \\
\text { Method }\end{array}$ & $\begin{array}{l}\text { Ra roughness, } \\
\text { cutting force, } \\
\text { cutting tool } \\
\text { wear }\end{array}$ & $\begin{array}{c}\text { Cutting } \\
\text { parameters: } \\
\text { cutting speed, } \\
\text { cutting feed }\end{array}$ & $\begin{array}{c}\text { nitrogen } \\
\text { alloyed } \\
\text { duplex } \\
\text { stainless } \\
\text { steel DSS } \\
\text { ASTM A } \\
995 \text { grade } \\
5 \mathrm{~A} \text { and } \\
\text { grade 4A }\end{array}$ & $\mathrm{L}_{9} 2^{3}$ & $\begin{array}{c}\text { SN } \\
\text { (STB)\& } \\
\text { ANOVA }\end{array}$ \\
\hline
\end{tabular}




\begin{tabular}{|c|c|c|c|c|c|c|}
\hline [7] & $\begin{array}{l}\text { Taguchi } \\
\text { Method }\end{array}$ & $\begin{array}{c}\text { Surface } \\
\text { roughness Ra }\end{array}$ & $\begin{array}{c}\text { Cutting } \\
\text { parameters: } \\
\text { cutting speed, } \\
\text { cutting feed, } \\
\text { cutting depth } \\
\& \text { cutting tool } \\
\text { material }\end{array}$ & $\begin{array}{c}\begin{array}{c}\text { High- } \\
\text { alloy } \\
\text { white cast }\end{array} \\
\text { iron (Ni- } \\
\text { Hard) at } \\
\text { two } \\
\text { different } \\
\text { hardness } \\
\text { levels (50 } \\
\text { HRC and } \\
62 \text { HRC) }\end{array}$ & $\begin{array}{l}\mathrm{L}_{18} 4^{3}(2 \\
\text { levels for } \\
\text { cutting } \\
\text { tool } \\
\text { material })\end{array}$ & $\begin{array}{c}\text { SNR(STB } \\
\text { )\& } \\
\text { ANOVA }\end{array}$ \\
\hline$[8]$ & $\begin{array}{l}\text { Taguchi } \\
\text { Method\& } \\
\text { RSM }\end{array}$ & $\begin{array}{c}\text { Surface } \\
\text { roughness } R_{a} \\
\text { and } R_{z}\end{array}$ & $\begin{array}{c}\text { Cutting } \\
\text { parameters: } \\
\text { cutting speed, } \\
\text { cutting feed, } \\
\text { cutting depth }\end{array}$ & $\begin{array}{c}\text { AISI } 304 \\
\text { austenitic } \\
\text { stainless }\end{array}$ & $\mathrm{L}_{27} 3^{3}$ & $\begin{array}{c}\text { SNR } \\
\text { (STB)\& } \\
\text { ANOVA } \\
\text { and RSM } \\
\text { with } \\
\text { regression } \\
\text { alanalysis }\end{array}$ \\
\hline [9] & $\begin{array}{l}\text { Taguchi } \\
\text { Method }\end{array}$ & $\begin{array}{c}\text { Surface } \\
\text { roughness } R_{a} \\
\text { and } R_{z} \text { and } \\
\text { flank wear } \\
(\mathrm{VB})\end{array}$ & $\begin{array}{c}\text { Cutting } \\
\text { parameters: } \\
\text { cutting speed, } \\
\text { feed rate and } \\
\text { depth of cut }\end{array}$ & $\begin{array}{l}\text { Hardened } \\
\text { AISI } 4140 \\
(51 \text { HRC) }\end{array}$ & $\mathrm{L}_{9} 3^{3}$ & $\begin{array}{c}\text { SNR \& } \\
\text { ANOVA }\end{array}$ \\
\hline$[10]$ & $\begin{array}{l}\text { Taguchi } \\
\text { dynamic } \\
\text { approach } \\
\text { coupled } \\
\text { with a } \\
\text { proposed } \\
\text { ideal } \\
\text { function } \\
\text { model }\end{array}$ & $\begin{array}{l}\text { Dimensional } \\
\text { precision and } \\
\text { accuracy and } \\
\text { the surface } \\
\text { roughness } R_{a}\end{array}$ & $\begin{array}{l}\text { Coolant, } \\
\text { cutting speed, } \\
\text { feed, depth of } \\
\text { cut, coating } \\
\text { type, chip- } \\
\text { breaker } \\
\text { geometry, } \\
\text { nose radius } \\
\text { and shape of } \\
\text { the insert } \\
\end{array}$ & $\begin{array}{l}\text { A range of } \\
\text { steels }\end{array}$ & $\mathrm{L}_{18} 2^{1} \times 3^{7}$ & $\begin{array}{c}\text { SNR \& } \\
\text { ANOVA }\end{array}$ \\
\hline [11] & $\begin{array}{l}\text { Taguchi } \\
\text { Method }\end{array}$ & $\begin{array}{l}\text { Surface } \\
\text { roughness } \\
\text { (Ra) }\end{array}$ & $\begin{array}{l}\text { Insert radius, } \\
\text { feed rate, and } \\
\text { depth of cut }\end{array}$ & $\begin{array}{l}\text { AISI } 1030 \\
\text { steel bars }\end{array}$ & $\mathrm{L}_{9} 3^{3}$ & $\begin{array}{c}\text { SNR \& } \\
\text { ANOVA }\end{array}$ \\
\hline [12] & $\begin{array}{l}\text { Taguchi } \\
\text { Method }\end{array}$ & $\begin{array}{c}\text { Surface } \\
\text { roughness } \\
(\mathrm{Ra}), \text { tool } \\
\text { wear, power } \\
\text { consumption } \\
\quad \text { and } \\
\text { chip reduction } \\
\text { co-efficient }\end{array}$ & $\begin{array}{l}\text { Cutting speed, } \\
\text { feed rate and } \\
\text { depth of cut }\end{array}$ & $\begin{array}{l}\text { Hard } \\
\text { metal }\end{array}$ & $\mathrm{L}_{9} 3^{3}$ & $\begin{array}{l}\text { SNR \& } \\
\text { ANOVA, } \\
\text { multiple } \\
\text { regression } \\
\text { analysis }\end{array}$ \\
\hline
\end{tabular}

\subsection{The design of the experiment}

\subsubsection{The process to be optimized}

The process to be optimized is a turning process of a cast iron part (a forged shaft used in a mechanical mechanism), on a high performance CNC turning machine. Because the part is a precision part, it is very important to master the dimensional accuracy at different levels. For that scope, it was studied the influence of the two main cutting parameters on the external diameter accuracy, at different temperature measurement levels. It is very well known that the cutting process it is developed with heat generation and propagation as a gradient within 
the part's material, also. That temperature gradient changes the dimensional accuracy within the time. For underlining and researching this phenomenon, the external diameters were measured at 2 temperatures. The first diameter measurement was developed at the moment of machining, when the part is discharged automatically from the chuck (at $33,5^{\circ} \mathrm{C}$ ), and the second diameter measurement was measured at after several hours, after the coldness of the part, within the metrological laboratory environment (at $21,4{ }^{\circ} \mathrm{C}$ ). The part's superficial temperature was measured with an infrared pyrometer.

The material machined is a continuously cast spheroidal graphite iron EN (-1563)-GJS500-7 (GGG50). This kind of spheroidal graphite offers higher wear resistance, strength \& heat-treatment response compared to other materials while still possessing good machinability and excellent surface finishes. Noise and vibration damping are good in this grade. For further detailed data regarding the material, within the Table 2 and the Table 3 there are presented another properties.

Table 2. Chemistry(Typical Ranges) (Subordinate to Mechanical Properties) [13].

\begin{tabular}{|c|c|c|c|c|c|c|c|c|}
\hline Element & $\begin{array}{l}\text { Car } \\
\text { bon }\end{array}$ & $\begin{array}{l}\text { Silic } \\
\text { on }\end{array}$ & $\begin{array}{l}\text { Manga } \\
\text { nese }\end{array}$ & Sulphur & $\begin{array}{l}\text { Phosph } \\
\text { orous }\end{array}$ & $\begin{array}{l}\text { Magnes } \\
\text { ium }\end{array}$ & $\begin{array}{l}\text { Others / } \\
\text { Alloyin } \\
\text { g }\end{array}$ & Iron \\
\hline $\begin{array}{l}\text { Typical } \\
\text { values }\end{array}$ & $\begin{array}{l}3.25 \\
- \\
3.70\end{array}$ & $\begin{array}{l}2.40 \\
- \\
3.00\end{array}$ & $\begin{array}{l}0.10- \\
0.30\end{array}$ & $\begin{array}{l}0.005- \\
0.020\end{array}$ & $\begin{array}{l}0.015- \\
0.08\end{array}$ & $\begin{array}{l}0.04- \\
0.07\end{array}$ & Residual & Balance \\
\hline
\end{tabular}

Table 3. Mechanical Properties (Anticipated Values) [13].

\begin{tabular}{|c|c|c|c|}
\hline $\begin{array}{l}\text { EN-GJS 500-7:1997 } \\
\text { (GGG40) }\end{array}$ & $\begin{array}{l}\text { Tensile strength } \\
\text { UTS N/mm2 }\end{array}$ & $\begin{array}{l}\text { 0.2\% Proof Stress } \\
\text { N/mm2 }\end{array}$ & Elongation \% \\
\hline $25 \mathrm{~mm}-50 \mathrm{~mm}$ & 500 & 320 & 7 \\
\hline $55 \mathrm{~mm}-100 \mathrm{~mm}$ & 450 & 300 & 7 \\
\hline $105 \mathrm{~mm}-200 \mathrm{~mm}$ & 420 & 290 & 5 \\
\hline $205 \mathrm{~mm}-600 \mathrm{~mm}+$ & 420 & 290 & 5 \\
\hline \multicolumn{4}{|c|}{ Another characteristics: } \\
\hline \multicolumn{4}{|c|}{ - Brinell Hardness $170 \ldots 230$} \\
\hline \multicolumn{4}{|c|}{$\begin{array}{l}\text { - Microstructure - Contains Type } 1 \& 11 \text { nodular (spheroidal) graphite in accordance with ASTM } \\
\text { A247. The rim contains approximately } 200 / 250 \text { nodules/ mm2, and is predominately ferritic with } \\
\text { the core containing } 90 / 150 \text { nodules/mm2. The core matrix is mixed ferritic/pearlitic ( } 10-50 \% \\
\text { pearlite). Chill carbides will be less than } 5 \% \text {, well dispersed. }\end{array}$} \\
\hline \multicolumn{4}{|c|}{$\begin{array}{l}\text { - Heat Treat Response - EN-GJS-500-7 can be hardened by conventional methods but EN-GJS } \\
600-3 \text { is recommended. }\end{array}$} \\
\hline \multicolumn{4}{|l|}{ - Density - $7.3 \mathrm{~g} / \mathrm{cc}$} \\
\hline
\end{tabular}

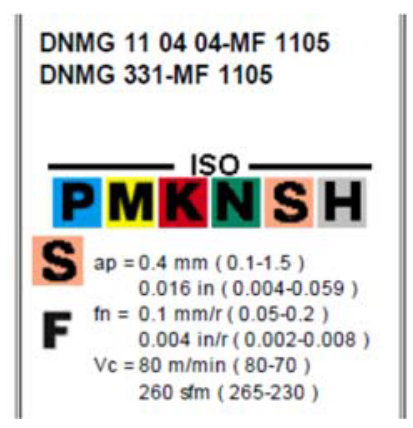

Fig. 3. The cutting insert used (DNMG 110404 MF 1105) for the turning process and the cutting data recommended ranges [14]. 
The turning process is developed with a DNMG 1104 04-MF 1105 cutting insert, withcorner radius $\left(\mathrm{R}_{\mathrm{E}}\right)$ of $0.3969 \mathrm{~mm}$ and made of a carbide that is grade 1105, coated by PVD with Aluminum oxide (Fig. 3). According with the same Fig. 3, the feed is recommended to be in the range $0.05 \ldots 0.2 \mathrm{~mm} /$ rot and the cutting speed is recommended to be adopted in the rage $80 \ldots 70 \mathrm{~m} / \mathrm{min}$.

The cutting tool wear was not took in consideration because the entire experiment was developed within the prescript range and the level of machining constituted by the 25 test parts does not influence on the wear.

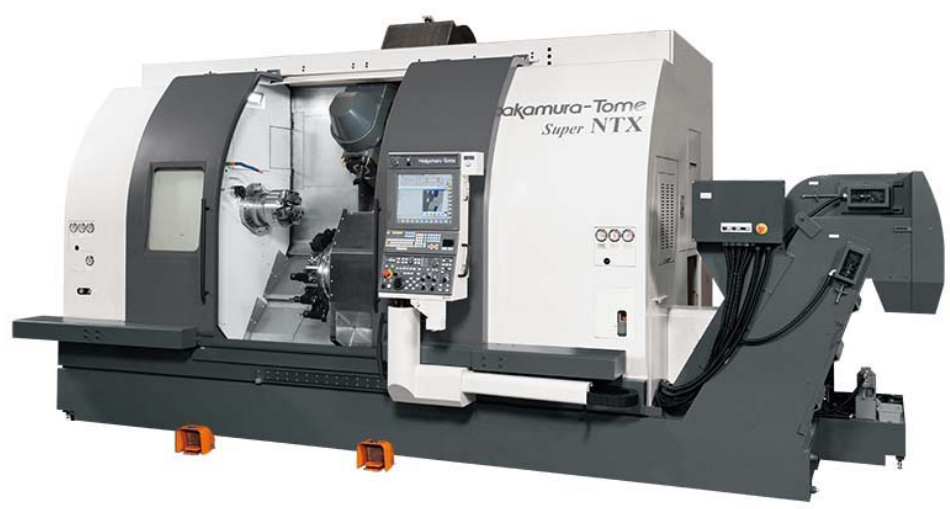

Fig. 4.The machine tool used for the experimentation [15].

Nakamura Super NTX is a CNC machine tool with twin spindle and twin turret. The used configuration can hold 24 tools on stock, the main spindle (for milling) turret can arrive at up to $8000 \mathrm{rot} / \mathrm{min}$ and the indexing range is on 230 degree ( \pm 115 degrees). The left and right spindles (for turning) can arrive up to $4500 \mathrm{rot} / \mathrm{min}$. The turrets can arrive at $3600 \mathrm{rot} /$ min for each of the 12 individual rotation tools stations from the total of 24 tools [15]. The forged workpiece initial diameter was $12 \pm 0.4 \mathrm{~mm}$ and the final turned nominal diameter is $10.9 \pm 0.1 \mathrm{~mm}$. Therefore, the radial cutting depth is $0.55 \mathrm{~mm}$.

\subsubsection{The process parameters and DoE}

Very accurate prescriptions for the cutting data it was not available for that particular application. Therefore, starting from the cutting tool producer's prescriptions (Fig. 3) there were considered 5 levels for the cutting speed parameter and 5 levels for the cutting feed parameter. The machine tool is a Nakamura high performance turning and milling HSM CNC (Fig.4).

As experimental matrix, it was selected an $\mathrm{L}_{25} 2^{5}$ fractioned factorial lattice. That means that the 2 experimental factors are variated at five levels each one, and the entire fractionated factorial design has 25 trials (Table4).

Table 4. The DoE - $\mathrm{L}_{25} 2^{5}$ fractioned factorial lattice and the correspondent parameter setup.

\begin{tabular}{|c|c|c|c|c|c|}
\hline \multirow{2}{*}{$\begin{array}{c}\text { Run } \\
\text { order }\end{array}$} & \multirow{2}{*}{$\begin{array}{c}\text { Level of } \\
\text { cutting speed }\end{array}$} & $\mathbf{v e}_{\mathrm{c}}$ & RPM & \multirow{2}{*}{$\begin{array}{c}\text { Level of } \\
\text { cutting feed }\end{array}$} & f \\
\hline & & {$[\mathrm{m} / \mathrm{min}]$} & {$[\operatorname{rot} / \mathrm{min}]$} & & {$[\mathrm{mm} / \mathrm{rot}]$} \\
\hline 1 & 1 & 70,0 & 1857,7 & 5 & 0,2000 \\
\hline
\end{tabular}




\begin{tabular}{|c|c|c|c|c|c|}
\hline 2 & 2 & 72,5 & 1924,1 & 4 & 0,1625 \\
\hline 3 & 5 & 80,0 & 2123,1 & 2 & 0,0875 \\
\hline 4 & 4 & 77,5 & 2056,8 & 4 & 0,1625 \\
\hline 5 & 1 & 70,0 & 1857,7 & 4 & 0,1625 \\
\hline 6 & 5 & 80,0 & 2123,1 & 3 & 0,1250 \\
\hline 7 & 5 & 80,0 & 2123,1 & 4 & 0,1625 \\
\hline 8 & 2 & 72,5 & 1924,1 & 2 & 0,0875 \\
\hline 9 & 1 & 70,0 & 1857,7 & 1 & 0,0500 \\
\hline 10 & 4 & 77,5 & 2056,8 & 5 & 0,2000 \\
\hline 11 & 2 & 72,5 & 1924,1 & 5 & 0,2000 \\
\hline 12 & 5 & 80,0 & 2123,1 & 1 & 0,0500 \\
\hline 13 & 3 & 75,0 & 1990,4 & 1 & 0,0500 \\
\hline 14 & 4 & 77,5 & 2056,8 & 2 & 0,0875 \\
\hline 15 & 5 & 80,0 & 2123,1 & 5 & 0,2000 \\
\hline 16 & 3 & 75,0 & 1990,4 & 4 & 0,1625 \\
\hline 17 & 1 & 70,0 & 1857,7 & 3 & 0,1250 \\
\hline 18 & 3 & 75,0 & 1990,4 & 2 & 0,0875 \\
\hline 19 & 1 & 70,0 & 1857,7 & 2 & 0,0875 \\
\hline 20 & 2 & 72,5 & 1924,1 & 3 & 0,1250 \\
\hline 21 & 3 & 75,0 & 1990,4 & 3 & 0,1250 \\
\hline 22 & 3 & 75,0 & 1990,4 & 5 & 0,2000 \\
\hline 23 & 2 & 72,5 & 1924,1 & 1 & 0,0500 \\
\hline 24 & 4 & 77,5 & 2056,8 & 3 & 0,1250 \\
\hline 25 & 4 & 77,5 & 2056,8 & 1 & 0,0500 \\
\hline
\end{tabular}

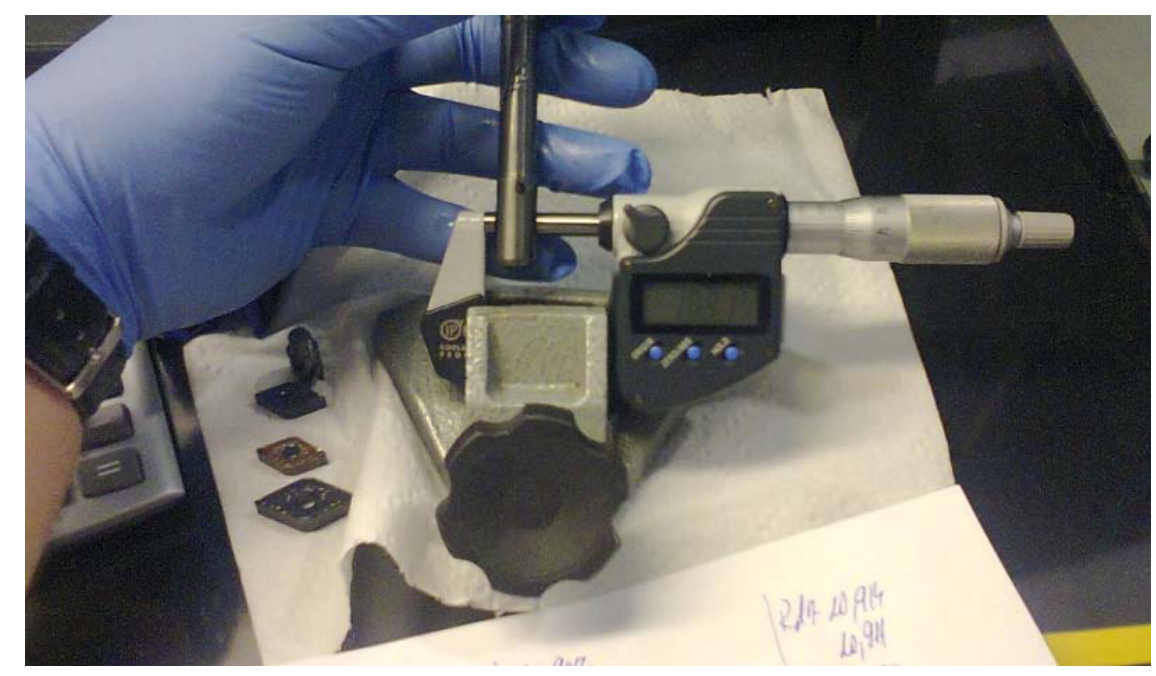

Fig. 5. The measurement of the external shift diameter (workshop and laboratory environment). 


\subsubsection{The metrological validation of the gage used for measuring}

The measurement system used is a QuantuMike Mitutoyo micrometer (Fig. 5), IP 65 Coolant Proof wired directly at a PC station with MeasurLink version 7.4.10 full configuration [16].

An important moment for the measuring process is the measurement instrument and process metrological validation, done by applying the GRR methodology (Fig. 6). The overall GRR index has the value of $2.7 \%$ and the number of the distinct categories is 8 , fact that validate the measuring process (the repeatability, reproducibility and the resolution are appropriate for that particular case).

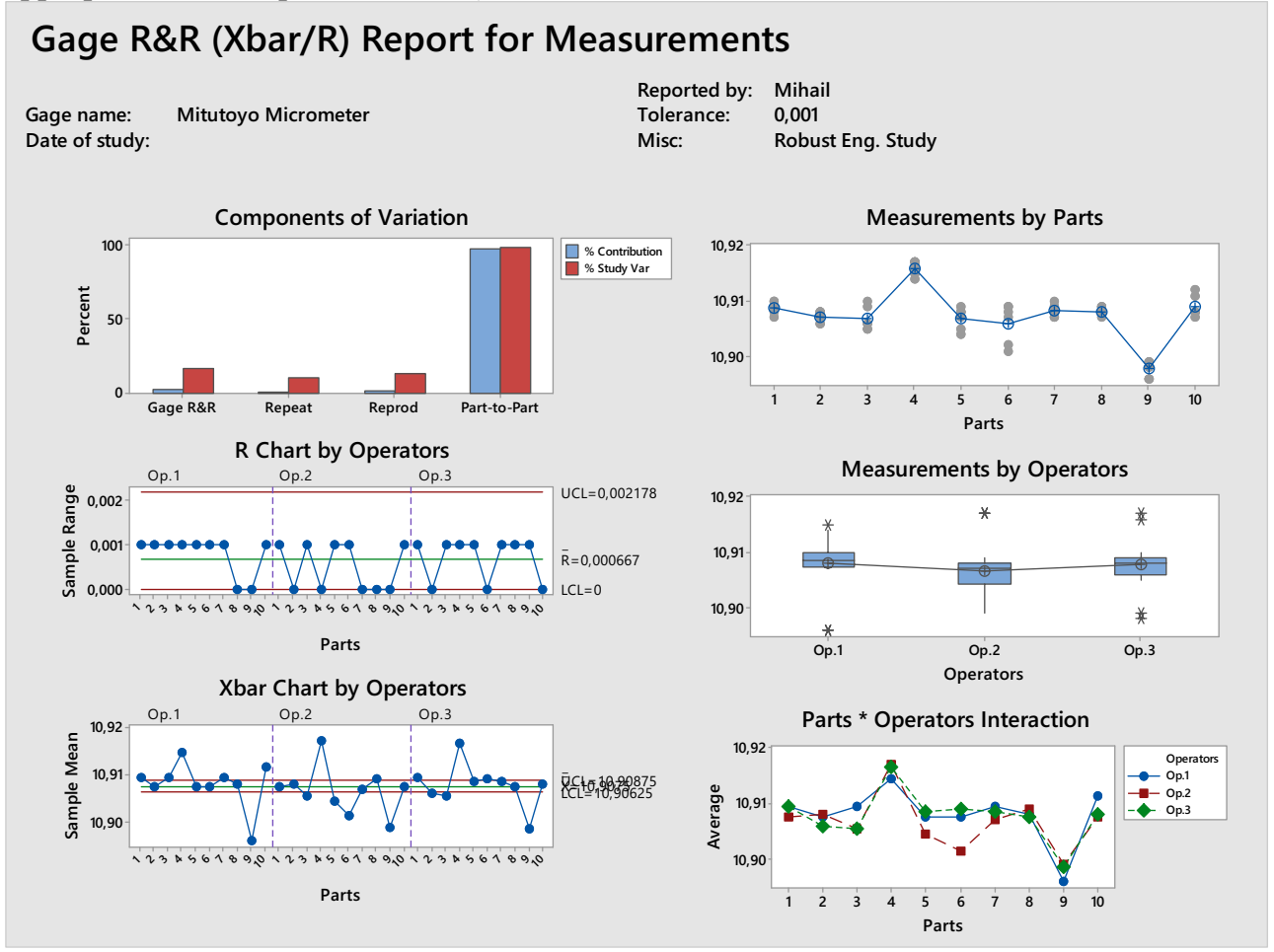

Fig. 6. Gage Repeatability and Reproducibility study results.

\section{Results, data analysis and conclusions}

\subsection{Experimental results, the data analysis and conclusions}

The 25 machined parts were measured at 2 different material temperatures and the final results are presented graphically analyzed by ANOM (see Fig. 7, Fig. 8 and Fig. 9).

The Fig. 7 presents the analysis of means (ANOM) of the influence on the test piece external diameter measured immediately after being machined (at a material temperature of $\left.33,5^{\circ} \mathrm{C}\right)$. Therefore, there are presented the influence on the specified characteristic of the

"A" factor (cutting speed) and the "B" factor (cutting feed). For each factor, by ANOM, there are computed the means of the values for each one of the 5 experimental levels of the researched parameters. With dotted line it is represented the mean of means.

The Fig. 8 represents an ANOM graphic obtained by the same approach as the one from Fig. 7 , but it is for the measurements obtained by measuring the test parts in laboratory 
environment, after that the parts material arrived at $21,4{ }^{\circ} \mathrm{C}$ (after 15 hours of thermal stabilization in an ambient temperature of $20,0{ }^{\circ} \mathrm{C}$ ).

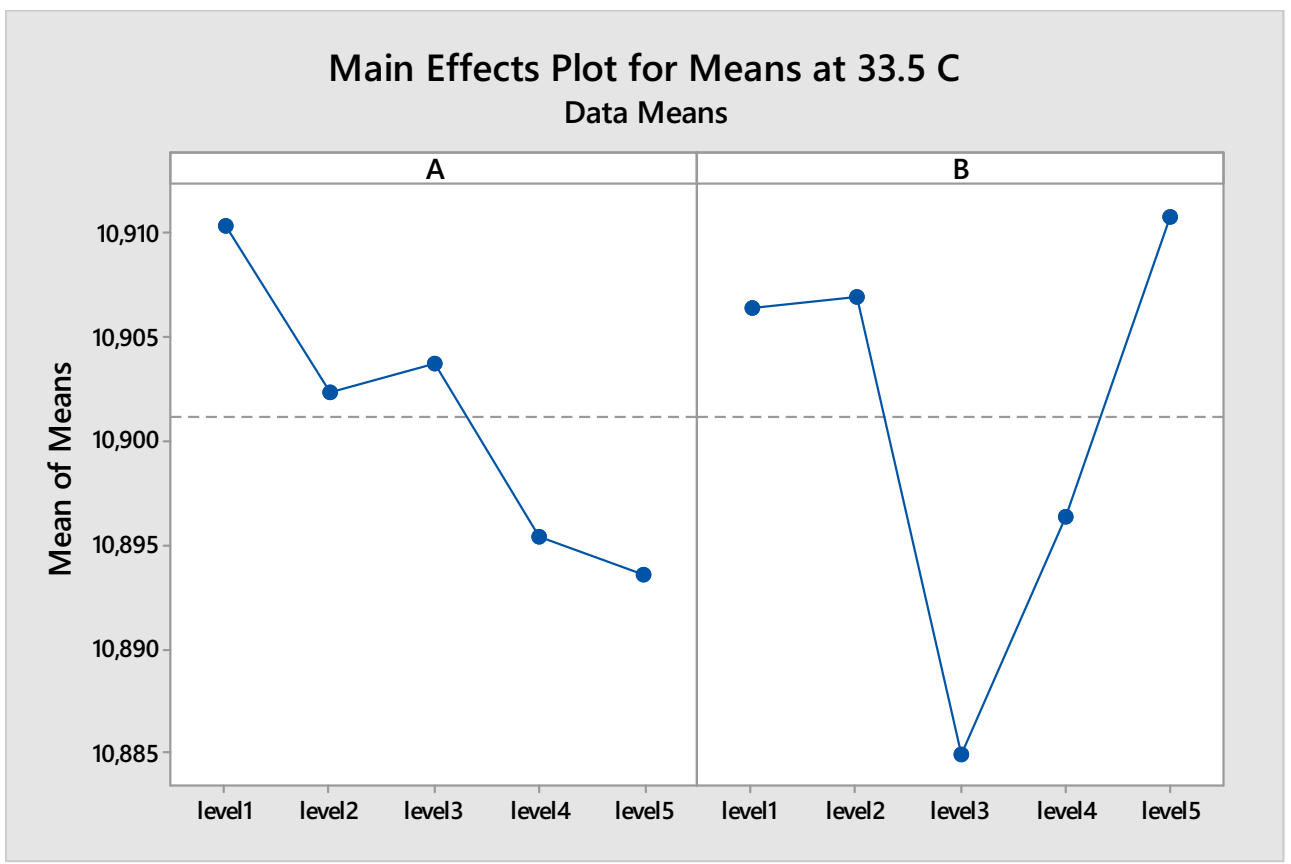

Fig. 7. ANOM for the measurements of the external shift diameter (workshop environment).

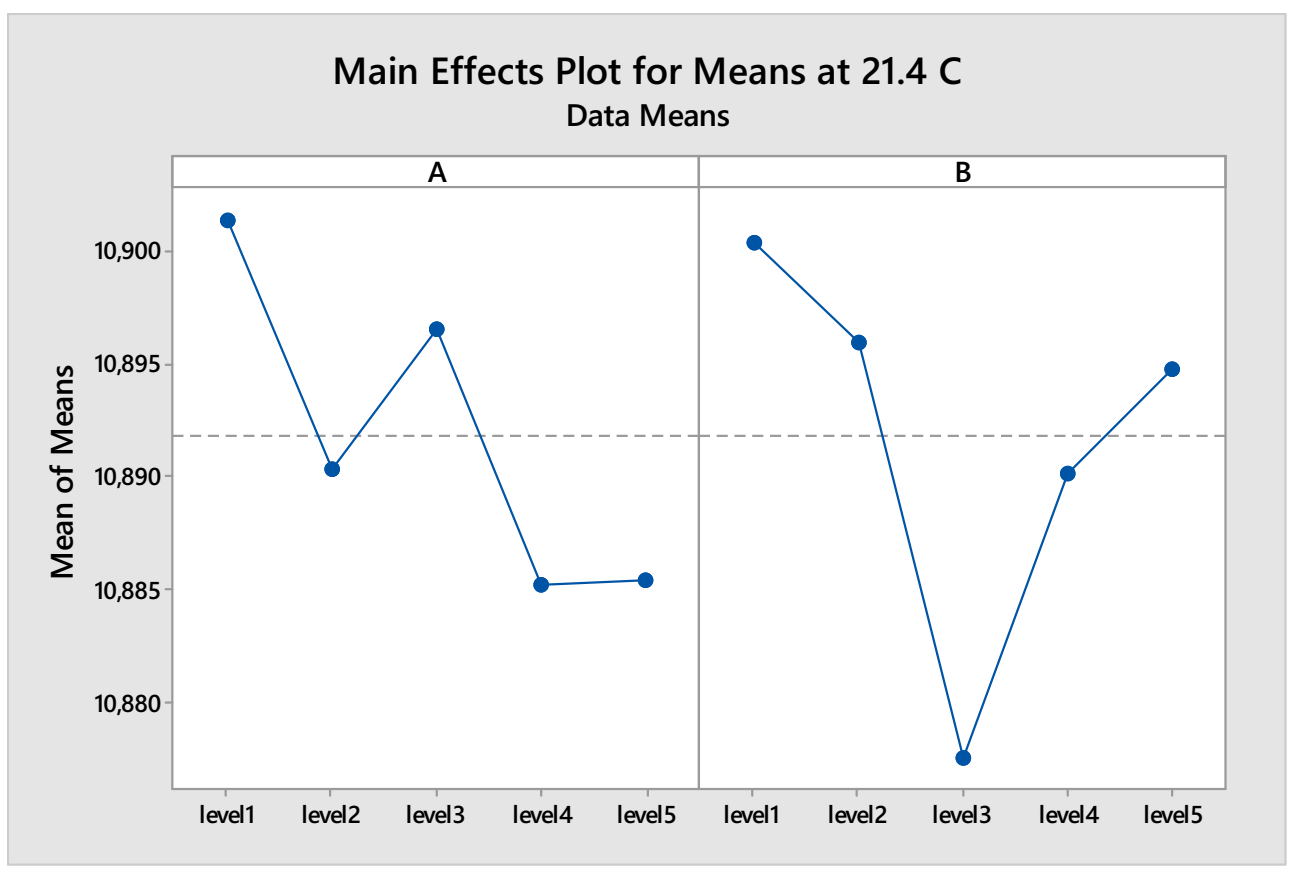

Fig. 8. ANOM for the measurements of the external shift diameter (laboratory environment). 


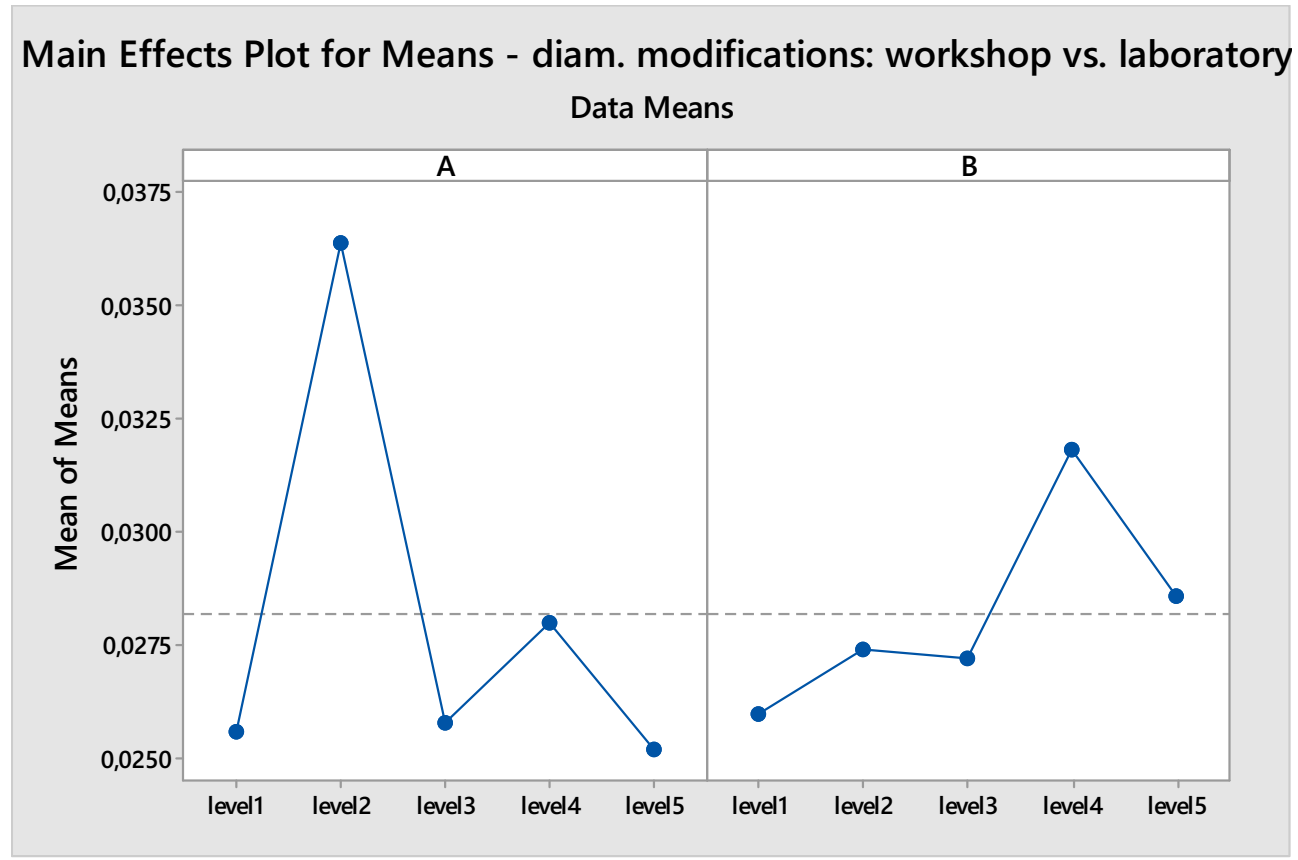

Fig. 9. ANOM for the range of the dilatation / contraction of the external shift diameter (workshop and laboratory environment).

According with Fig. 7 and Fig. 8, the general trend for the external diameter is to decrease once the cutting speed ("A" parameter) is increasing. The phenomenon is considered to be validated by theory knowing that the heat gradient is growing in intensity once the cutting speed increases. The dilatation of the cutting tool system and of the part's material generate that decrease of part's external diameter. The same trend is underlined by the measurements developed within the laboratory environment.

According with the same Fig. 7 and Fig. 8, the influence of the raise of the cutting feed ("B" parameter) present an inflexion point at the third level of the experimental parameter. Also, it can be observed by comparing the two graphics that the influence of the two researched parameters on the diameter's variation range is a little bit higher for the cutting feed case than of the cutting speed case.

Also, it can be observed that the level of influence on the external dimeter of the two experimental parameters range is practically the same (approximatively $6 \mu \mathrm{m}$ ), by comparing the diameters measured before and after contraction.

The final remarks can be extracted from the Fig. 9 that present the dilatation / contraction range. Therefore, the best cutting process setup would be at the first levels of the two parameters: $\mathrm{v}_{\mathrm{c}}=70 \mathrm{~m} / \mathrm{min}$ and $\mathrm{s}=0,05 \mathrm{~mm} /$ rot. Because of economic reasons, it can be considered to be better to higher the level of two parameters, reason for which it can be choose their third levels $\mathrm{v}_{\mathrm{c}}=75 \mathrm{~m} / \mathrm{min}$ and $\mathrm{f}=0,125 \mathrm{~mm} /$ rot. To continue the compromise by gaining more productivity and losing some accuracy, it can be choose the fifth levels $\mathrm{v}_{\mathrm{c}}=$ $80 \mathrm{~m} / \mathrm{min}$ and $\mathrm{f}=0,2 \mathrm{~mm} /$ rot.

The results were took in consideration for the next batch of pieces and the optimization was, in that manner, confirmed. The surface quality (dimensional and roughness) was measured and the results were according with the customer's requirements. 


\subsection{Future development}

As future developments, it is interesting to take in consideration the roughness quality characteristic for a simultaneous optimization of the turning process. Also, it may be opportune the change of the tool's insert grade and taking this parameter in consideration as a distinctive experimental parameter within the factorial lattice, for future optimization developments.

The measurements realized in the present research were made using the infrastructure of the"Mitutoyo Metrology Laboratory" from the "Institute High Tech Products for Sustainable Development: PRO-DD" of "Transilvania" University of Brasov, laboratory created with the contribution of Mitutoyo Romania S.R.L.

Table 5.Abbreviations.

\begin{tabular}{|c|c|}
\hline Abbreviation & Meaning \\
\hline PVD & Physical Vapor Deposition \\
\hline DoE & Design of Experiments \\
\hline HSM & High Speed Machining \\
\hline CNC & Computer Numerically Controlled \\
\hline $\mathrm{L}_{\mathrm{a}} \mathrm{b}^{\mathrm{c}}$ & Lattice with a runs for b factors variated at c levels \\
\hline SNR & Signal to Noise Ratio \\
\hline STB & Smaller The Best (Better) \\
\hline ANOVA & ANalysis Of VAriation \\
\hline ANOM & ANalysis Of Means \\
\hline IP & Instrument Protection \\
\hline GRR & Gage Repeatability and Reproducibility \\
\hline Xbar / R & Average and Range \\
\hline & \\
\hline
\end{tabular}

\section{References}

1. G.Taguchi, S. Chowdhury, Y. Wu, Taguchi's Quality Engineering Handbook (John Willey \& Sons and ASI, 2004)

2. L.-A. Mihail, Proceedings of MEQAPS '13, 60 (2013)

3. A. Aggarwal, H. Singh, Sadhana Vol. 30, Part 6, 699 (2005)

4. A. R. Yildiz, Applied Soft Computing 13, 1433 (2013)

5. C.-J.Tzenga, Y.-H.Linb, Y.-K. Yanga, M.-C.Jeng, Journal of Materials Processing Technology 209 ( 2009 ) 2753-2759

6. D. P.Selvaraj, P. Chandramohan, M. Mohanraj, Measurement 49, 205 (2014)

7. M.Günay, E.Yücel, Measurement 46, 913 (2013)

8. I.Asiltürk, S.Neseli, Measurement 45, 785 (2012)

9. I.Asiltürk, H.Akkus, Measurement 44, 1697 (2011)

10. Y.-F. Tzeng, Materials and Design 27, 665 (2006)

11. M. Nalbant, H. Gokkaya, G. Sur, Materials and Design 28, 1379 (2007)

12. A. Das, A. Khan, S. Mohanty, Lean Thinking 6 (2015)

13. www.gefebe.com, accessed at 30 Aug. 2016

14. http://www.sandvik.coromant.com/en-us/products/Pages/productdetails.aspx? $\mathrm{c}=\mathrm{dnmg}$ $\% 2 \mathrm{~B} 11 \% 2 \mathrm{~B} 04 \% 2 \mathrm{~B} 04-\mathrm{mf} \% 2 \mathrm{~B} 1105 \& \mathrm{~m}=5732258 \&$ Country=ro accessed at $30 \mathrm{Aug}$. 2016

15. http://www.nakamura-tome.co.jp/products/en/atc/super-ntx.html, accessed at 30 Aug. 2016

16. www.measurlink.com,accessed at 30 Aug. 2016 